\title{
Genetics of Parkinsonism
}

\author{
G Annesi \\ From de Senectute: Age and Health Forum \\ Catanzaro, Italy. 5-7 December 2009
}

Parkinson's Disease (PD), the second most frequent neurodegenerative disorder after Alzheimer's disease (six million patients world-wide), is generally diagnosed after the sixth decade. It causes motor dysfunctions, such as bradykinesia, resting tremor, rigidity and postural instability, but also affects autonomic functions and cognition. PD results mainly from progressive degeneration of dopaminergic neurons in the substantia nigra and other monoaminergic cell groups in the brainstem, increased microglial activation and accumulation of proteins in surviving dopaminergic neurons, known as Lewy bodies and Lewy neurites. The etiology of PD is unknown, although older age and neurotoxins are established risk factors, and smoking appears to be protecitive. In the last decade, several causative genes and susceptibility factors have been identified in rare families with Mendelian inheritance, and suggest that abnormal handling of misfolded proteins by the ubiquitin-proteosome and authophagy-lysosomal systems, increased oxidative stress, mitochondrial and lysosomal dysfunctions, and other pathogenic dysfunctions, contribute to PD. Although PD was long considered a non genetic disorder of sporadic origin, $5-10 \%$ of patients are now known to have monogenic forms of the disease. At least, 13 loci and 9 genes are associated with both autosomal dominant (PARK1 and PARK4/alpha-synuclein (SNCA); PARK5/UCHL1;PARK8/LRRK2;PARK11/ GIGYF2,PARK13/Omi/Htra2) and autosomal recessive (PARK2/Parkin; PARK6/PINK1; PARK7/DJ-1;PARK9/ ATP13A2) PD. Monogenic forms represent less than $10 \%$ of PD in most populations. The vast majority result from complex interactions among genes and between genes and environmental factors. Genetic variations may be susceptibility factors or disease modifiers, affecting penetrance, age at onset, severity and progression. High-density arrays of single nucleotide polymorphisms (SNPs) permit the identification of susceptibility factors

Institute of Neurological Sciences, National Research Council, Piano Lago di Mangone (CS), Italy in genome- wide association (GWA) studies, in which the frequencies of putative risk alleles are compared in patients and controls. The identification and characterization of Mendelian forms of PD and association studies in sporadic PD patients delineating molecular pathways that are involved in dopaminergic cell dysfunction and death.

Published: 19 May 2010

\section{References}

1. Annesi G, Savettieri G, Pugliese P, et al: DJ-1 mutations and parkinsonismdementia-amyotrophic lateral sclerosis complex. Ann Neurol. 2005, 58(5):803-7.

2. Sidransky E, Nalls MA, Aasly JO, Aharon-Peretz J, Annesi G, et al: Multicenter analysis of glucocerebrosidase mutations in Parkinson's disease. $N$ Engl J Med. 2009, 22;361(17):1651-61.

doi:10.1186/1471-2318-10-S1-L29

Cite this article as: Annesi: Genetics of Parkinsonism. BMC Geriatrics 2010 10(Suppl 1):L29.

Submit your next manuscript to BioMed Central and take full advantage of:

- Convenient online submission

- Thorough peer review

- No space constraints or color figure charges

- Immediate publication on acceptance

- Inclusion in PubMed, CAS, Scopus and Google Scholar

- Research which is freely available for redistribution

Submit your manuscript at www biomedcentral com/submit 